\title{
The Epistemic Oppression of the Veil
}

\author{
Gehad Abdelal \\ Department of Philosophy, Cairo University, Giza, Egypt \\ Email: Gehad.mohamed@cu.edu.eg
}

How to cite this paper: Abdelal, G. (2017) The Epistemic Oppression of the Veil. Open Journal of Social Sciences, 5, 1-12. https://doi.org/10.4236/jss.2017.59001

Received: June 25, 2017

Accepted: August 29, 2017

Published: September 1, 2017

Copyright $\odot 2017$ by author and Scientific Research Publishing Inc. This work is licensed under the Creative Commons Attribution International License (CC BY 4.0).

http://creativecommons.org/licenses/by/4.0/

\begin{abstract}
The veil is one of the essential phenomena in the Islamic world. Many Islamic and western feminist studies analyzed the veil. The Islamic feminism considers the veil as a free choice and a representation of the Islamic identity. On the other hand, one group of the feminism of the West counts the veil as oppression and a threat to the western modernity. However, both studies tackle the veil issue from the framework of free choice and identity without enough analyzing to the epistemological framework that surrounds it. Therefore, this paper investigates the epistemic oppression of the veil in the Islamic world by examining the claim of "the veil is a free choice". The study will result in three situations of re-situatedness to the right-wing, external re-situatedness and re-situatedness to contrary epistemic system. These outcomes could refute the claim that the veil could be analyzed through the free choice structure, whether it is oppression or a gift.
\end{abstract}

\section{Keywords}

Veil, Epistemic Oppression, Situatedness, Free Choice, Islamic World, Fundamental Discourse

\section{Introduction: Why the Epistemic Oppression of the Veil?}

Why are we concerned about the epistemic oppression of the veil? In general, there are at least three prima facie reasons. Firstly, to understand the current politics in the Islamic world, we need to recognize the veil's symbolic role within the contemporary Islamic context. Secondly, for analyzing and understanding women's problems in this world, we should focus on the veil as both a norm and practice. Thirdly, the veil represents a core explanation of the current war in the Middle East. These reasons are important for interdisciplinary studies of international affairs, cultural exchanges, and political theory. However, there is a specific significance of studying the veil for the field of philosophy and feminist epistemology in particular. The veil represents a physical control over female's 
body along with oppression of social and religious knowledge in non-western context. In the Islamic countries, it shows how the institutions created epistemic oppression against women through the veil. The fundamental discourse, which dominates these countries, used institutional ignorance to convince females that they should wear the veil and to believe that wearing the veil is a free choice at the same time. It is not just a piece of clothing; it is a lifestyle. Moreover, they turned the veil to be an identity; the female life is centralized around it. For the feminist epistemology field, this paper will provide a view of expanding the feminist epistemology to frame non-western women problems.

Generally speaking, the feminist literature, in tackling of the veil phenomenon, is divided into four approaches. A first approach is a western approach, which considers the veil as social-religious oppression against females in the Islamic world. Sometimes, the veil is counted as a legal oppression, in cases such as Afghanistan, Iran and Saudi Arabia. The feminists in this approach also consider the veil in the western world as oppression against females and a threat to Western modernity as well. A second approach is a western approach that advocates females' right to choose to wear the veil. The third approach is Islamic feminism ${ }^{1}$, which considers the veil as the Islamic identity and God's demand. The fourth approach is the non-Islamic feminism, and this movement is an Eastern movement that aims to free women from the theocratic domination. The feminists in this approach explicitly acknowledge the veil as a psychological and social oppression.

These four approaches analyze the veil in the Islamic countries without enough consideration to the epistemic system that constructed around the veil. Besides, all four of these approaches shape the veil into two notions: the veil is a free choice, and the veil represents the Islamic identity. It is significance to indicate that, in this paper, the discussion focuses on females who live in the Islamic world and already wearing the veil.

I pen to this paper to argue that the veil in the Islamic world is not a free choice, which mainly disputes against the Islamic feminism and both types of the western feminism. This paper is divided into two parts. The first part is the literature, where I will indicate most common views about the veil. In the second part, I will analyze the claim that the veil is a free choice. The methodology is analyzing questioning the veil in its epistemic context through employing feminist epistemology.

\section{Literature (Four Views of the Veil)}

The veil has a long history of representing the faith in many cultures and religions, such as Judaism, Christianity, Hinduism, Sikhism, and Islamism. However, in Islamic discourse, the veil becomes a representation of Islamic political system $^{2}$ and the identity of Muslim females.

${ }^{1}$ Islamic feminism is a religious movement discusses women rights through the religion text. ${ }^{2}$ The Islamic political system mainly means that the state legislations are written based on Islamic religion legislation. 
I should declare that there are two issues about the veil in the Islamic world. The first, there is an uncertainty regarding whether the veil is one of the first demands in Islamic faith or not. Islam religion writings are not entirely explicit on the question of female veiling. Many statements in the Quran and the Hadith (statements attributed to the prophet Muhammed) make reference to $\mathrm{Mu}$ hammed's wives' veiling, but it is controversial whether such declarations apply only to the prophet's wives or all Muslim females. Chronologically, the veil was neither compulsory nor widely adopted until generations after Muhammed's death (2005) [1]. This view is not acceptable in many Islamic states; sometimes these states fight back those who believe in such interpretation. Ultimately, the contrary interpretation, the fundamental interpretation, assures that the veil is a God's demand and structures the Islamic identity. Prominently, the fundamental interpretation is widespread throughout all Islamic countries. The controversial issue of whether the veil is an Islamic demand or not is still confined to the academic level not expanded to the social level yet. It could be the methodology of how the fundamental interpretation became dominant is the reason of limiting this issue to the academic level only. Then, the question is how the fundamental interpretation, or "the veil becomes standard", became dominant in the Islamic world, in last five decades?

Now, the second issue shows how the veil became that standard, passing all different cultures, historical, and ecological aspects of each country in Islamic countries, whether Arabic or non-Arabic speakers. Elsaadawi argues that the governments, whether theocratic or secular, in the Islamic countries are responsible for that fundamental domination. "Governments give the fundamentalists access to TV and media, and under the name of democracy they allowed to issue their own newspapers and magazines" (1997) [2]. With the fact that the media shapes the social consciousness development, so the media was the powerful tool that helped the fundamental discourse to form the social mind, in last five decades. The daily TV programs that support the fundamental interpretation have influenced females to believe that the salvation is the veil. However, most feminist studies did not give enough analysis to how the fundamental movements impact epistemologically on females. Moreover, most of these studies determined the discussion into what the fundamental movements said about the veil as a fact, not just an opinion. In response to the domination of the fundamental discourse, most feminist studies that tackle the veil issue have analyzed the veil within this discourse.

The feminist studies are divided into mainly three approaches regarding the veil issue. The first approach is the Western approach. The anti-veil Western view considers the veil as an oppression against Muslim females in the Islamic countries, and it is a threat to modernity in the Western world. In France, the United States and Canada, the veil represents the non-modernity and fear of Islamism. Bowen argues that the French society established a law to ban the veil to protect the community from Islamism (Islamic identity), communalism and 
sexism (2007) [3]. On the other hand, the with-veil Western view participants advocate for the female right to wear the veil. Superson, in her paper "Right-Wing women: causes, choices and blaming the victim"; draws a question: is the female's right to choose to live under patriarchy and to use the benefits from that, or not? She then addressed the dilemma of if we consider it the female's right to free herself from the inferior position in patriarchy world, why we do not consider the same "right to live" and "get benefits" from being inferior in the patriarchal society? (1993) [4]. Nussbaum considers banning the veil in Europe to be embracing the politics of fear and turning the community against the modernity values of freedom. She also says that every woman should be free to show her own identity (2010) [5].

The second approach is the Islamic feminism approach; Amina in her article "Conflits internes des savoirs chez les étudiantes musulmanes portant le foulard islamique" argues that Muslim females wear the veil in schools to affirm their identity vis-à-vis French society (2004) [6]. Syed in his article "Hijab gives Muslim women the chance to practice feminism in their own way" argues that Islam offers a reliable and robust defense of women's rights, and this reinforces the reason Muslim women choose to wear the headscarf. Because wearing the scarf is, for many Muslim women, a way to practice feminism (2014) [7].

Most Islamic feminists employ the case of females wearing the veil in the western world to generalize two ideas; the first idea is that they choose freely to wear the veil in public. The second idea is that they want to represent their own identity while encountering the others in the western identity. In fact, expanding the case of the veil arguments from the non-Islamic society to the veil inside the Islamic society turns the Islamic feminists' arguments into fragile context. Most Islamic states do not have culture diversity, so that the female can represent herself through the veil. Besides, the domination discourse in these states imposes the veil as the extreme necessity in the female's life. Thus, this way of arguing supports the epistemological oppression of the veil in the Islamic countries, because it considers the position of women who wear veil in the western society as the same as the female's veil position in the Islamic society.

The third approach is the Eastern non-Islamic feminism, which is against the Islamic feminism approach. These feminists explicitly say that the fundamental discourse of Islamic religion is the reason of damaging the Islamic countries, socially and politically. Eltahawy believes that Islam as a fundamental context is responsible for raising misogyny in the Middle East more than anywhere else. Therefore, the veil is one of most visible pieces of evidence of this misogyny (2012) [8]. Elsaadawi, also blames the Middle East regimes for allowing fundamentalists to dominate the society, and in most cases, these governments employ this fundamentalist approach to control the public, Arab spring revolution is an evidence of the effectiveness of this utilization.

There are two main observations, based on the literature I have searched. Firstly, both Islamic and western approaches focus essentially on females who 
wear the veil in the western world. They discussed the female existence and agency in the light of the conflict between Western modernity and fundamentalism. The second note is they framed wearing the veil by free choice and identity, without considering the epistemology that directs females who are born in the Islamic world. These women live and die in the Islamic world, with everything around them built up to make them believe that their battle in the world is to represent the Islamic identity, along with understanding this representation as a free choice. In this paper, I will analyze the case of wearing the veil as an epistemic oppression of free choice, whether as oppression as the western approach or non-oppression as the Islamic approach. The veil is not simply a free choice.

\section{The Epistemic Aspect of the Veil}

One of Islamic feminism's central claims is women choose freely to wear the veil to obey God. Females choose God's way of protecting them from men. God demands the veil for women's own benefits, which include protecting them from men's abuse in public. Besides, women wear the veil will protect men from female's beauty influences. These are fundamental principles that always structure the epistemic aspect of the veil. The result, as these feminists expected, is the veil should be keeping the Sin away from the Islamic community. However, based on statistics, the Muslim countries have the highest record ${ }^{3}$ of sexual harassment in public. Despite all these realities, the claim that wearing the veil is a free choice and for women's protection remains to exist and effective.

In fact, there are many questions regarding the meaning of the female's decision to subject herself to the veil freely. Do the Muslim females in the Islamic world choose the Islamic religion? The answer is no, almost all Muslim females born into the Islamic faith. Even if we agreed with the claim that she was born to find herself a Muslim woman, and then she willingly accepted this religion, the question would remain; does she allowed to interpret or express her understanding of the Islamic text as a female believer? Or does she have to accept the men's interpretation of the text? If the claim of wearing the veil is a female's free choice is true, then not wearing the veil is a free choice as well? I argue that the free choice, in this case, is not as simple as choosing between $\mathrm{X}$ and $\mathrm{Y}$, or just between wearing the veil or not wearing the veil. The issue is more complicated than that. Before I attempt to answer these questions, which arise directly from the Islamic feminism claims, I need to discuss how the epistemology of the veil in Islamic world works.

\section{Situatedness to the Veil System Not Only Wearing It}

The veil itself, in the Islamic world, is far more just a piece of cloth. It represents social, religious, ethical and political notions. The definition of situatedness based on Pohlhaus account is "the knower's situatedness refers to the situations

${ }^{3}$ https://themuslimissue.wordpress.com/2013/07/11/statistics-muslim-countries-obsessed-with-wom ens-honour-have-one-of-the-highest-rape-scales-in-the-world/ 
in which the knower finds herself repeatedly over time due to the social relations that position her in the world" (2012) [9]. The female gets exist to find herself situated to a particular physical appearance in public. With profounding Pohlhaus' definition, the female knower in the position of "situatedness" has to show herself into the veil as a practice of wearing it as clothes along with believing in specific norms of mental and emotional capacities. ${ }^{4}$ These capacities are defined by men who have religious authority within the fundamental discourse.

The argument that the Islamic feminism made is:

- The veil is an Islamic demand, premise one.

- The interpretation of the "Islamic demands" "Fiqh" is a male mission, premise two (2011) [10].

- The conclusion is the male who frames the situatedness to the veil for the females.

In general, men use the resilience of interpretation of Islamic religion as a text to establish domination over the female. Moreover, because the Islamic discourse indicates that the ability to interpret the text is given to the man only, it was so easy to exclude her knowledge from Islamic epistemic system. Based on this argument, we can analyze the epistemic oppression of the veil.

\section{The Epistemic Oppression of the Veil}

\subsection{Exclusion of the Female's Knowledge}

The primary step to create this situatedness is to exclude the female as a knower of her physical appearance from the female physical appearance knowledge production. Dotson in her paper "Conceptualizing Epistemic Oppression" defines epistemic oppression as it "refers to the persistent epistemic exclusion that hinders one's contribution to knowledge production" (2014) [11]. Excluding the female knowledge about what is comfortable ${ }^{6}$ for her to wear, and what is not comfortable in particular, is the initial step for replacing female knowledge about her physical appearance with the male definition of female physical appearance. However, the fundamentalists realized that only excluding the female knowledge in the process of constructing the social and political knowledge is not adequate to completely control women without resistance. For instance, women revolution in Egypt after 1919, Hoda Shaarawi, Nabawiyya Musa and Ceza Nabarwi are the leaders of this revolution; the women resisted against traditionalism and Islamic fundamentalism by taking the veil off. After that date, the fundamental movements considered the women resistance seriously.

${ }^{4}$ These mental and emotional capacities are such as: she has to be obeyed to the man, not to raise her voice, or to speak indelicate words, not walk at night outside, not argue against any decision made by the man... these practices in the Islamic feminism called the veil's moral system.

${ }^{5}$ Fiqh is the human understanding of the Sharia-sharia expanded and developed by interpretation of the Quran and Sunnah by Islamic jurists (Ulama) and implemented by the rulings (Fatwa) of jurists on questions presented to them.

${ }^{6}$ Comfortable refers in this point mainly to ecological and medical aspects. Wearing the veil in countries with high temperature causes suffering from raising the body temperature, stress, sweating and hair loss. 
The fundamental discourse has constructed oppression against unveiled, even females who question the veil to limit any potential resistance. This oppression appears at the moment when the female decides to take off this veil. Based on the fact that the female is excluded from the knowledge production of wearing the veil, let's examine the position of questioning the veil. The questioning analysis should reveal the epistemic oppression of the veil and defeat the Islamic feminism and the western feminism claim of wearing the veil is a free choice.

\subsection{Re-Situatedness to Right-Wing Position}

The medical and sexual harassment issues may point females to question the veil in media, social media, work, home, or school. In general, this questioning may lead the female to realize that there is something wrong with being obligated to be situated to the veil. In most cases, the veil issue emerges in the discussion of the identity and the conflict between fundamentalism and modernity, and sexual harassment in public. Before she, as a knower, frames questioning the veil into linguistic phrases, she would recognize that some other issues stem from the veil questioning. The fundamentalists focused deeply on the language pattern to power their discourse, (1997) [2]. The fundamentalists turn the language, through their broad media, to "function of certain kinds of speech to silence a targeted (female) group" (2015) [12]. To serve this silencing, they divided the language into "safe" and "dangerous". Moreover, silencing females as what Fricker called "credibility deficit" is to situate females into doubting their ability to question as rational knowers in general and in the Religion's demands in particular (2007) [13]. For instance, one of the hazardous questions is the question of the veil, because the veil is structured in the Islamic world for female through the faith. If she doubts the veil, inevitably she will doubt the faith and God existence.

This situation expresses two kinds of epistemic violence. Firstly, the female fears of falling in either bad faith or losing the way to God. Secondly, female fears of being seen in the society as she is in a bad faith or lost her way to God. These fears may create another kind of the epistemic violence. The female compares between the epistemic violence of being situated to the veil ${ }^{7}$ and the epistemic violence of questioning the veil "losing faith and society's support". The female as a knower has a strong connection to the social-religious position, so questioning the knowledge of the veil becomes dangerous. The fundamental movement aims to make it difficult to deconstruct the cause and effect relationship between faith and the veil. Most females choose to not to shape the epistemic oppression of the veil into linguistic phrases (questioning) to avoid the oppression of the society. They prefer not to say why they wear the veil, or why they believe that the veil is a religious demand.

Despite the fact that the female may refuse or fears to question the veil because

${ }^{7}$ Note, realizing the veil oppression means that she thinks that wearing the veil in high temperature places is injustice and the veil does not really protect her from sexual harassment along with the people society still believe that the veil prevents the men abuse. 
of the former reasons; the idea of the questioning the veil creates disturbance in her epistemic system. Now, how she will solve this issue of confusion? She may choose to eliminate this disturbance through two methods. The first method is to get herself re-convinced with the dominant narratives of the fundamental discourse that provide written reasons of why she should be situated to veil. This re-convincing process is assembled through the idea of the truth of God's existence. Alcoff explains that by saying: "all we need for justification is to establish the belief's connection to truth... the main reason to have a theory of justification is to show how a belief if true or likely to be true" $(1996,2007)$ [14] [15]. For instance, the female believes that the God exists and the most popular interpretation of God's demands assures that the veil is a God's order. Then, the truth of God's existence will support the fact of the veil demand. This method is the negative $^{8}$ part of re-situating herself to the fundamental God-veil connection. This re-situating is what Dotson called contributory injustice that "is caused by an epistemic agent's situated ignorance, in the form of willful hermeneutical resources that result in epistemic harm to the epistemic agency if a knower" (2012) [16]. The female may re-read, re-listen, re-watch the fundamental resources, which support the God-veil connection directly, trying to get rid of the disturbance of the idea of questioning the veil. However, this negative method is not enough to get her out from the questioning circle. She needs to DO something.

The second method is the positive part ${ }^{9}$ of re-situatedness. The female may start to be an advocate of this situatedness to the veil $(1994,2006)$ [17] [18]. She endeavors to establish the right-wing epistemology that "can reinforce patterns of dominance by providing a rational for knowledge-collection practices that advantage members of certain social groups (who become experts and researchers) are the expense of others (who are restricted to being informants or objects to be known)" (2006) [19]. Once, she starts to convince other females about how being situated to the veil is necessary for faith and ethical principles; she will get support from the society. This support will help her to stabilize her beliefs again. From this point, she will become a right-wing ${ }^{10}$ female in the society; she will accept the epistemic oppression of being situated to the veil, and advocates for it. She will choose ignorance to give herself the stability (2007) [20]. Thus, it is not accurate to claim that those advocates females of wearing the veil, they did that from a free choice, or they choose the veil for ethical or religious principles, they re-situated themselves to it to avoid the epistemological violence. However, not all females who encounter questioning the veil choose the same direction as right-wing females.

\footnotetext{
${ }^{8}$ The negative method means in this part that she is absent as a critical knower, she in this method accepts the discourse as it is. Some philosophical and hermeneutics literature indicates that part of knowing as a position of negative receiver.

${ }^{9}$ The positive method means when the female decides to add her own experience of being situated to the veil to the fundamental discourse and then use herself as an example of how the veil gives her many benefits.

${ }^{10}$ Right-wing term is taken from Anita M. Superson paper: "Right-Wing women: causes, choices, and blaming the victim"
} 


\subsection{External Re-Situatedness}

Regularly as the fundamental discourse epistemic system, questioning the veil entails questioning the religious belief and the social position. In this level of re-situatedness, the female realizes that to avoid the fear of losing her faith; she must solve the problem of amalgamating faith with the veil. Before, the fundamentalists could prevent publishing books, or any knowledge resources, that give an alternative religious interpretation, but this method is not that effective anymore. With the increasing prevalence of internet use, a variety of resources for religious interpretation, especially for the veil issue, have become more accessible. To be clearer, the female in this position, for some reason, could get rid of her fear of losing faith by questioning the veil. She realizes that she was situated as a knower to fundamental discourse, which targets to establish a gap in resources of religious knowledge. Dotson called it a "reliable ignorance", which means that "ignorance that is consistent or follows from a predictable epistemic gap in cognitive resources" (2011) [21]. Female may find that there is another opinion around the God-veil connection differs from what is given. Ultimately, she should find alternative knowledge resources that could provide a reasonable statement or rational interpretation that explains why the veil is not a God's demand.

If she finds an alternative epistemic resource of the veil issue, which indicates that there is no connection between the belief in God and wearing the veil, $(2012,1997)$ [2] [8] as Non-Islamic feminism always advocates for, then she may face an epistemic violence. This violence emerges from the fact the world around her has been structured through the fundamental discourse. The language, values, and practices are dominated by this discourse. Therefore, if she gets convinced with the alternative epistemic resource that provides a strong claim that there is no connection between the faith and the veil, then the disturbance will not only affect the faith values but also will affect all her social and political values. This disturbance in the epistemic system will leave her in the violence between believing in the fundamental discourse values to avoid the social oppression or to take the challenge to change her epistemic system.

Now, she is convinced of the veil is not a God's demand, and must choose between being compelled to wear the veil as a social obligation, or to take it off and to be positioned as "unethical". The veil is a wide phenomenon; the average percentage of females wearing the veil in the Islamic world could reach more than $85 \%{ }^{11}$. Therefore, the challenge for the female in that position is to choose between to take the veil off along with accepting the social oppression against females who took their veil off or to keep wearing the veil while she does not believe in it. For instance, by questioning the veil or taking the veil off, this would bring dishonor to her family. People in the society will disrespect her if she decides to take the veil off. Therefore, she realizes that the society, upon the fundamental discourse, will situate her into a position of being unethical female. As Khader

${ }^{11}$ http://markhumphrys.com/islam.human.rights.html 
account of "Adaptive preferences", this second level of external re-situatedness will meet her approach of adaptive preferences, because "the oppressed may suppress what was once an active desire to question to avoid the pain and dissonance of wishing for a better world that will never come" (2012) [22]. The epistemic violence herein is to choose between being situated to the veil as a social obligation not a religious obligation, or being situated to an unethical position.

In this level of questioning the veil, she believes that the veil is a social-political oppression, but she is not able to fight against this social oppression. She does not want to lose her family, job or respect in the society. This understanding would force her to choose half-resituated herself to the fundamental dominated world. She will change her beliefs along with continuing to wear the veil from the justification of sacrifices to avoid the stronger oppression. The epistemic violence in this position is to live two epistemic systems; the first is the fundamental epistemic system and the second is her new epistemic system. Eventually, because she is epistemologically trapped between two concepts, it is not right to consider this female choice is a "free" choice. Thus, this level of external situatedness is a second common among females' responses to questioning the veil. However, the less common response is the situation where the female decides to take the veil off.

\subsection{Re-Situatedness to the Contrary Epistemic System}

In this level, the female attained to free herself from the fundamental epistemic system, she could take the veil off, and she ruled the veil out. Before she can take this decision, she had to face multiple kinds of epistemic violence. She could pass the level two of external-re-situatedness position to free herself from internal and external situatedness to the veil. This positioning means that she must accept the position of being disrespected, dishonored and epistemologically excluded from the knowledge production in general. This external re-situatedness is "irreducible epistemic oppression". Dotson called it the third-order of epistemic oppression, "to say that such resources (the fundamental discourse resources) are inadequate is to throw into question the relevance of given community's overall dominant resources in light of the knowledge production activities in question... third-order epistemic exclusion proceeds from the 'outside' of a set of epistemic resources to throw large portions of one's epistemological system into question as a result of the goals of a given inquiry" (2014) [11]. Moreover, she should accept the situation of resistance, or as Medina says, the "epistemic friction" (2013) [23]. I do not claim here that the female was getting any respect or honor while she was situated to the veil; however, she is only gaining support from the epistemic community. However, the level of disrespect and dishonor while she is taking the veil off is too high, and she loses the support from the epistemic community. Taking off the veil could cause much physical and psychological harm (2004) [24]. To endorse that the veil is a free choice, it should be available and easy to choose not to wear the veil. The epistemic op- 
pression that appears from taking off the veil makes the free choice to not choose the veil not existed. Thus, the veil is not a free choice.

In conclusion, the claim that females in Islamic world wear the veil from a free choice point of view is not that simple and in many cases not accurate. If the Islamic feminism or the Western feminism consider the re-situatedness to the right-wing position is a free choice, then by examining the questioning the veil would show how this claim fails to meet the description of a free choice and shows how far the epistemic oppression involves into situatedness to the veil.

\section{Conclusion}

The veil is not that simple to restrict it to mere wear it or not. Wearing the veil represents epistemic oppression, and questioning it creates another epistemic oppression. Therefore, focusing on the veil phenomenon in the Islamic world is the core of understanding the epistemic system of this world. Especially, the fundamental movement, which established the veil under two claims: the veil is the female free choice, and the veil represents the Muslim identity. Excluding the female from the producing the religious knowledge makes it difficult to accept that she chooses the veil freely. The analysis of questioning the veil reveals epistemic oppression. Thus, three outcomes result from questioning the veil: re-situatedness to the right-wing, external re-situatedness or re-situatedness to a contrary epistemological system can refute the claim that the veil is a free choice. These three outcomes indicate explicitly that the epistemological analysis of the veil can construct a new wave of studying the veil aside from limiting it to social, religious and psychological oppression. Moreover, focusing on the epistemic oppression of the veil can give us a strong tool to point the gaps in knowledge resources, and this should result in developing resistance against the fundamental discourse for females who live in the Islamic world. In the future, I will continue working on the epistemic analysis of the veil as Muslim female identity and how this scope represents the structure of politics in the Islamic world.

\section{References}

[1] Aslan, R. (2005) No God but God. Random House, New York, 66-67.

[2] El Saadawi, N. (1997) The Nawal El Saadawi Reader. Zed Publisher, London.

[3] Bowen, J.R. (2007) Why the French Don't Like Headscarves. Princeton University Press, Princeton, NJ, 156. https://doi.org/10.1515/9781400837564

[4] Superson, A.M. (1993) Right-Wing Women: Causes, Choices, and Blaming the Victim. Journal of Social Philosophy, 24, 40-61 https://doi.org/10.1111/j.1467-9833.1993.tb00523.x

[5] Nussbaum, M. (2010) Veiled Threats? New York Times, NYTimes.com. http://opinionator.blogs.nytimes.com/2010/07/11/veiled-threats/20

[6] Amina, T.Y. (2004) Conflits internes des savoirs chez lesétudiantes musulmanes portant le foulard islamique. Carrefours de l'éducation, 1, 22-40. https://doi.org/10.3917/cdle.017.0022

[7] Rizvi, S. (2014). 
http://www.dailytexanonline.com/2014/06/26/hijab-gives-muslim-women-the-chan ce-to-practice-feminism-in-their-own-way

[8] Eltahawy, M. (2012) Why Do They Hate Us? In: Newsweek Interactive LLC, Ed., Foreign Policy, Washington Post, Washington DC, 64-70, 81-84.

[9] Gaile Jr., P. (2012) Relational Knowing and Epistemic Injustice: Toward a Theory of Willful Hermeneutical Ignorance. Hypatia, 27, 715-735. https://doi.org/10.1111/j.1527-2001.2011.01222.x

[10] Hosseini, Z.M. (2011) Hijab by Choice: Between Politics and Theology. In: Kamrava, M., Ed., Innovation in Islam: Traditions and Contributions, University of California Press, Oakland, CA, 190-212.

[11] Dotson, K. (2014) Conceptualizing Epistemic Oppression. A Journal of Knowledge, Culture and Policy, 28, 115-138. https://doi.org/10.1080/02691728.2013.782585

[12] Stanley, J. (2015) How Propaganda Works. Princeton University Press, Princeton, 128. https://doi.org/10.1515/9781400865802

[13] Miranda, F. (2007) Epistemic Injustice: Power\& the Ethics of Knowing. Oxford University Press, Oxford, 17-19.

[14] Alcoff, L.M. (1996) Real Knowing: New Versions of the Coherence Theory. Cornell University Press, Ithaca, New York, 55.

[15] Alcoff, L.M. (2007) Epistemologies of Ignorance: Three Types. In: Shannon, S. and Nancy, T., Eds., Race and Epistemologies of Ignorance, State University of New York, New York, 39-58.

[16] Dotson, K. (2012) A Cautionary Tale: On Limiting Epistemic Oppression. Frontiers, 33, 24-47. https://doi.org/10.5250/fronjwomestud.33.1.0024

[17] Cudd, A.E. (1994) Oppression by Choice. Journal of Social Philosophy, 25th Anniversary Special Issue, 22-44. https://doi.org/10.1111/j.1467-9833.1994.tb00347.x

[18] Cudd, A.E. (2006) Analyzing Oppression. Oxford University Press, Oxford. https://doi.org/10.1093/0195187431.001.0001

[19] Townley, C. (2006) Toward a Revaluation of Ignorance. Feminist Epistemologies of Ignorance, 21, 37-55. https://doi.org/10.1111/j.1527-2001.2006.tb01112.x

[20] Bailey, A. (2007) Strategic Ignorance. In: Shannon, S. and Nancy, T., Eds., Race and Epistemologies of Ignorance, State University of New York, New York, 77-93.

[21] Dotson, K. (2011) Tracking Epistemic Violence, Tracking Practices of Silencing. Hypatia, 26, 236-257. https://doi.org/10.1111/j.1527-2001.2011.01177.x

[22] Khader, S.J. (2012) Must Theorising about Adaptive Preferences Deny Women's Agency? Journal of Applied Philosophy, 29, 302-317. https://doi.org/10.1111/j.1468-5930.2012.00575.x

[23] Medina, J. (2013) The Epistemology of Resistance: Gender and Racial Oppression, Epistemic Injustice, and Resistant Imaginations. Oxford University Press, Oxford, 27-55. https://doi.org/10.1093/acprof:oso/9780199929023.001.0001

[24] Crawford, M. and Rhoda, U. (2004) Women and Gender: A Feminist Psychology. 4th Edition, The McGraw Hill Companies, New York. 
Submit or recommend next manuscript to SCIRP and we will provide best service for you:

Accepting pre-submission inquiries through Email, Facebook, LinkedIn, Twitter, etc. A wide selection of journals (inclusive of 9 subjects, more than 200 journals)

Providing 24-hour high-quality service

User-friendly online submission system

Fair and swift peer-review system

Efficient typesetting and proofreading procedure

Display of the result of downloads and visits, as well as the number of cited articles Maximum dissemination of your research work

Submit your manuscript at: http://papersubmission.scirp.org/

Or contact jss@scirp.org 